\title{
WUJUD DAN FUNGSI ALIH KODE PENUMPANG TERHADAP KRU BUS TRAYEK SOLO-JOGJA
}

\author{
Wahyu Oktavia \& Ferdian Achsani \\ Institut Agama Islam Negeri Surakarta \\ Email: oktaviawahyu17@gmail.com, dwikurniawan219@gmail.com
}

\begin{abstract}
Abstrak:
"Penelitian ini bertujuan untuk mendeskripsikan serta menelaah wujud dan fungsi alih kode pada tindak tutur penumpang dengan kru bus trayek Solo-Jogja. Data ini diperoleh dari tuturan penumpang, kru bus dan sopir bus trayek Solo-Jogja. Metode yang digunakan adalah metode diskriptif kualitatif yang data-datanya diperoleh, diklasifikasikan, dianalisis dan selanjutnya diperoleh suatu gambaran umum tentang data-data yang diteliti serta menggunakan metode observasi yang berupa teknik simak, teknik rekam, dan teknik wawancara. Hasil penelitian ini ada tiga: (1) wujud variasi alih kode penumpang terhadap kru bus trayek Solo-Jogja, (2) fungsi alih kode penumpang terhadap kru bus trayek Solo-Jogja, dan (3) faktor penyebab terjadinya alih kode penumpang terhadap kru bus trayek Solo-Jogja."
\end{abstract}

Kata kunci: wujud, fungsi, alih kode, kru bus

\section{PENDAHULUAN}

Manusia sebagai makhluk sosial selalu melakukan interaksi dengan orang lain. Keterkaitan manusia dengan orang lain menyebabkan manusia memanfaatkan suatu bahasa sebagai alat komunikasi. Diartikan sebagai alat komunikasi karena bahasa sendiri digunakan dalam kehidupan sehari-hari. Dengan bahasa, seseorang dapat berhubungan dengan orang lain. Bahasa tidak digunakan secara individu melainkan dihubungkan dengan kegiatan di dalam masyarakat, sehingga dapat dikatakan bahwa bahasa tidak dipandang sebagai unsur individu melainkan juga sebagai unsur sosial. ${ }^{1}$

Bahasa merupakan alat komunikasi yang berupa sistem lambang bunyi yang menjadi alat ucap manusia. ${ }^{2}$ Selain itu, bahasa juga sebuah alat komunikasi yang digunakan oleh setiap individu dalam menjalin interaksi sosial dalam kehidupan masyarakat. Maksud atau tujuan komunikasi sendiri dapat dibedakan menjadi tiga macam, yaitu: bersifat manusiawi, bersifat naluri, dan bertautan dengan hal-hal emosi. ${ }^{3}$ Selain itu, bahasa juga merupakan sebuah sistem, berwujud lambang, berupa bunyi, bersifat arbitrer, bermakna, konvensional, unik, universal, produktif, dinamis, sebagai wujud identitas diri, dan bahasa itu bervariasi apabila dikembangkan menjadi secara lebih luas.

\footnotetext{
${ }^{1}$ Priliana Budi. Patmawati, 'Campur Kode Dan Alih Kode Pada Acara Show Imah Di Trans TV’ (Universitas Jember., 2013).

${ }^{2}$ Khodiyo. Thesa, 'Penggunaan Alih Kode Dalam Percakapan Pada Jaringan Whatsaap Oleh Mahasiswa KNB Yang Berkuliah Di Universitas Sebelas Maret', Prasasti, 2.1 (2017), 89-101.

${ }^{3}$ Dewi Lagawati. Putri, ‘Alih Kode Dalam Acara Talk Show “Show Imah” Di Trans TV.' (Universitas Negeri Yogyakarta.).
} 
Dewasa ini, perkembangan masyarakat sudah semakin modern. Penguasaan bahasa yang semakin banyak menjadikan kekuatan mereka untuk bersaing di dalam dunia bahasa, sehingga tidak jarang terjadi pergantian penggunaan bahasa satu dengan bahasa lain dalam proses komunikasi. Kenyataan di atas mengakibatkan adanya variasi kode-kode yang telah dikuasai masyarakat menjadikan adanya masyarakat yang multilingual, yaitu yang menguasai banyak bahasa, dan masyarakat yang bilingual, yaitu yang menguasai dua bahasa. Seseorang dalam berbahasa tentu akan memilih kode sesuai dengan konteks, situasi, dan kondisi saat berkomunikasi.

Latar belakang situasi dan tuntutan menyebabkan terjadinya variasi dalam berbahasa. Bahasa tersebut bermacam-macam karena anggota masyarakat penutur bahasa itu beragam, dan bahasa itu digunakan untuk keperluan yang beragam pula. ${ }^{4}$ Dalam interaksi sosial sehari-hari, tanpa dirasa penutur telah menggunakan variasi bahasa. Dari variasi bahasa itulah yang selanjutnya akan lahir individu-individu yang memilih bahasa dalam melakukan komunikasi. Pemilihan bahasa merupakan gejala dalam aspek kedwibahasaan sebab di dalam reportoirnya terdapat lebih dari satu bahasa. ${ }^{5}$

Sebagai seorang yang terlibat dalam menggunakan dua bahasa tentu juga secara tidak langsung terlibat dalam dua budaya. Masyarakat yang menguasai dua bahasa atau lebih tentunya harus memilih salah satu bahasa untuk berkomunikasi. Pemilihan bahasa tersebut dalam kajian siosiolinguistik ada tiga jenis yaitu alih kode, campur kode dan variasi dalam bahasa yang sama. ${ }^{6}$

Menurut Patmawati menyimpulkan bahwa dalam penelitiannya "Campur Kode dan Alih Kode Pada Acara Show Imah di Trans TV" hasil penelitian ini menunjukkan bahwa terdapat tujuh puluh tiga yang diidentifikasi memuat unsur linguistik, bentuk campur kode, jenis alih kode, faktor yang melatarbelakangi campur kode, dan faktor yang melatarbelakangi alih kode. ${ }^{7}$ Tuturan tersebut biasanya berupa kata, frase, ungkapan atau idiom, serta jenis alih bahasa dan alih variasi bahasa.

Sepihak dengan pendapat di atas, menurut Putri Dewi Lagawati dalam penelitiannya yang berjudul "Alih Kode Dalam Acara Talk Show Imah di Trans TV" hasil penelitiannya ada dua kesimpulan. ${ }^{8}$ Berdasarkan jenisnya alih kode dibagi menjadi dua yaitu alih kode intern dan alih kode ekstern. Alih kode intern mencakup dua jenis yaitu alih kode antarragam dan alih kode antarbahasa. Alih kode antarragam yang ditemukan adalah alih kode dari ragam formal bahasa Indonesia ke ragam informal bahasa Indonesia dan dari ragam informal bahasa Indonesia ke ragam formal bahasa Indonesia. Berbeda dengan dua pendapat di atas, menurut Wulansari Nanik dalam penelitiannya yang berjudul "Wujud dan Fungsi Alih Kode Penumpang Awak Bus Trayek

\footnotetext{
${ }^{4}$ Abdul Chaer., Linguistik Umum. (Jakarta: Rieneka Cipta).

${ }^{5}$ A. Nugroho, 'Alih Kode Dan Campur Kode Pada Komunikasi Guru-Siswa Di SMA Negeri 1 Wonosari Klaten.' (Program Sarjana Universitas Negeri Yogyakarta.).

${ }^{6}$ Sumarsono, Sosiolinguistik (Yogyakarta: Sabda, 2008).

${ }^{7}$ Patmawati.

${ }^{8}$ Putri.
} 


\section{Wahyu Oktavia \& Ferdian Achsani}

Jepara-Semarang" yang mengatakan bahwa wujud alih kode terdiri dari alih kode intern dan alih kode ekstern. Selain itu, fungsi dari alih kode dalam penelitian ini disebutkan sebagai pemberian informasi dan pengakraban antarindividu serta faktor-faktor yang mempengaruhi alih kode diantaranya yaitu SPEAKING (Situation, Participant, Ends, Act, Key, Instrument, Norms dan Genre). ${ }^{9}$

Dalam penelitian ini, peneliti memilih tempat di dalam bus di sepanjang trayek perjalanan Solo-Jogja yang terdiri dari Sopir, kenek, kondektur dan penumpang yang mengandung tuturan alih kode. Uniknya lagi dalam penelitian ini banyak kajian yang menarik untuk dikaji, dimana penelitian tersebut merupakan unsur kedwibahasaan yang memiliki mobilitas gerak tinggi sehingga akan terlihat banyak penggunaan dua bahasa atau lebih secara bergantian. Tujuan dari penelitian ini adalah: (1) Mendeskripsikan wujud variasi alih kode penumpang terhadap kru bus pada trayek Solo-Jogja, (2) Menjelaskan fungsi alih kode penumpang terhadap kru bus pada trayek Solo-Jogja, (3) Faktor-faktor yang menyebabkan terjadinya alih kode penumpang terhadap kru bus pada trayek Solo-Jogja.

\section{KAJIAN TEORI}

Penelitian ini lebih dipusatkan pada wujud alih kode dalam pilihan bahasa, karena alih kode merupakan salah satu aspek tentang ketergantungan bahasa di dalam masyarakat multilingual dan hampir seluruh masyarakat memakai lebih dari satu bahasa dalam komunikasinya yang ditandai dengan konteks dan fungsi dari masing-masing bahasa. ${ }^{10}$ Selain itu, alih kode merupakan pemakaian bahasa atau kode yang sesuai dengan konteks yang dipendamnya. ${ }^{11}$

Dengan begitu, alih kode diartikan suatu pergantian pemakaian bahasa karena situasi yang berbeda. ${ }^{12}$ Berbeda dengan pendapat ahli tersebut, menurut Hymes dalam (Chaer dan Agustina) mengatakan bahwa alih kode itu bukan hanya terjadi antar bahasa, tetapi dapat juga terjadi antara ragam-ragam atau gaya-gaya yang terdapat dalam satu bahasa. ${ }^{13}$ Lebih tepatnya lagi ia mengatakan bahwa "code switching has become a cammon term for alternate us of two or more language, varieties of language, or even speech style."

Alih kode adalah istilah umum untuk menyebutkan pergantian antara pemakai dua bahasa atau lebih, variasi dari satu bahasa dan berbagai gaya dalam satu ragam. ${ }^{14}$ Menurut Romaine dalam (Giyoto) alih kode adalah pergantian penggunaan dari bahasa satu ke bahasa yang lain dan pola-pola peralihan bahasa tertentu memegang peranan yang sangat penting dalam reportoar komunikasi tertentu. ${ }^{15}$ Sependapat dengan pendapatnya, menurut Bell dalam (Giyoto) terjadinya

\footnotetext{
${ }^{9}$ Nanik Wulansari, "Wujud Dan Fungsi Alih Kode Penumpang Dan Awak Bus Trayek Jepara-Semarang", (Universitas Diponegoro Semarang, 2013).

${ }^{10}$ Wulansari.

${ }^{11}$ Thesa.

${ }^{12}$ Abdul Chaer and Leonie. Agustin, Sosiolinguistik. (Jakarta: PT Rineka Cipta).

${ }^{13}$ Chaer and Agustin.

${ }^{14}$ Diyah Atiek. Mustikawati, ‘Alih Kode Dan Campur Kode Antara Penjual Dan Pembeli (Analisis Pembelajaran Berbahasa Melalui Studi Sosiolinguistik).', Dimensi Pendidikan Dan Pengajaran, 3.2, 1-10.

${ }^{15}$ Giyoto., Pengantar Sosiolinguistik. (Surakarta: Fata Press).
} 
alih kode dikarenakan setiap orang memiliki beberapa peran dalam berbagai situasi yang setiap peran ini mempunyai norma-norma perilaku tertentu. ${ }^{16}$ Salah satu norma perilaku itu adalah perilaku pemakaian bahasa. Berbeda dengan Kridalaksana yang menegaskan bahwa alih kode adalah penggunaan variasi bahasa lain untuk menyesuaikan diri dengan peran atau situasi lain atau karena ada partisipasi lain. ${ }^{17}$

Dalam keadaan kedwibahasaan seseorang sering melakukan pergantian bahasa atau ragam bahasa secara tidak sadar. Hal tersebut terlihat pada keadaan serta keperluan mereka saat berbicara. ${ }^{18}$ Pada kondisi bilingual penutur seringkali mengganti unsur-unsur bahasa atau tingkat tutur. Alih kode juga diartikan sebagai kejadian apabila seseorang melakukan peralihan dari satu bahasa ke bahasa yang lain. Misalnya ragam akrab atau dari dialek satu ke dialek yang lain, atau dari tingkat tutur tinggi seperti (kromo inggil) ke tuturan yang lebih rendah seperti (ngoko) dan sebagainya. ${ }^{19}$

Alih kode merupakan suatu peristiwa peralihan dari satu kode ke kode yang lainnya. ${ }^{20}$ Oleh sebab itu, apabila seorang penutur mula-mula menggunakan kode A (misalnya bahasa Indonesia), maka peristiwa pengalihan kode menggunakan kode B (misalnya bahasa Jawa), dan hal inilah yang dinamakan alih kode (code-swiching). Akan tetapi, di dalam suatu kode terdapat berbagai kemungkinan baik varian rasional, kelas sosial, ragam gaya atau pun register. Dengan demikian, peristiwa alih kode ini disebabkan karena adanya alih varian, alih ragam, alih gaya, atau alih register. Dalam alih kode, penggunaan dua bahasa atau lebih itu ditandai oleh masing-masing bahasa yang disesuaikan dengan situasi yang relevan serta perubahan konteks.

Hymes (dalam Suwito) mengatakan bahwa alih kode adalah sebutan pergantian (peralihan) pemakaian dua bahasa atau lebih, yang terdiri dari beberapa variasi dari satu bahasa, serta beberapa gaya dari satu ragam bahasa. ${ }^{21}$ Alih kode bersifat intern apabila alih kode itu terjadi antarbahasa daerah dalam bahasa nasional, atau antara dialek dalam satu bahasa daerah, atau antar beberapa ragam dan gaya yang terlihat dalam satu dialek. Berbeda halnya dengan alih kode yang bersifat ekstern yakni apabila alih kode itu terjadi antara bahasa asli dengan bahasa asing.

Alih kode pada hakikatnya yakni tuturan bentuk yang tidak diintegrasikan dengan unsur bahasa -dari dua bahasa atau lebih- dengan tidak ada pergantian dari mitra tutur atau topik. Jadi, dapat disimpulkan bahwa alih kode adalah beralihnya bahasa penutur dari tataran satu lingual penegas, kata, frasa, klausa dan kalimat.

\section{METODE PENELITIAN}

Peneliti melakukan penelitian ini dengan metode kualitatif deskriptif yaitu suatu jenis metode dengan menghasilkan sebuah data deskriptif dalam bentuk kata-kata dan percakapan, baik lisan

\footnotetext{
16 Giyoto.

${ }^{17}$ Kristen. Kridalaksana, The Linguistics Encyclopedia. (London: Routledge).

18 Wulansari.

${ }^{19}$ P. W. J. Nababan, Sosiolinguistik: Suatu Pengantar. (Jakarta: PT Gramedia., 1986).

${ }^{20}$ Suwito, Sosiolinguistik Pengantar Awal (Surakarta: Henary Offset Solo, 1985).

${ }^{21}$ Suwito.
} 


\section{Wahyu Oktavia \& Ferdian Achsani}

maupun tulis. ${ }^{22}$ Selain menggunakan metode deskriptif kualitatif, penelitian ini juga menggunakan metode observasi. Dalam metode observasi ini digunakan teknik menyimak, merekam, dan wawancara. Setelah data terkumpul, langkah berikutnya yaitu menganalisis data. Analisis data ini bertujuan untuk membagi, mengklasifikasi, menganalisis, mengembangkan data sehingga mudah dibaca, dipahami serta diinterpretasikan. Hasil penelitian yang dilakukan dapat dikategorikan dalam analisis variasi dan fungsi serta faktor penyebab alih kode. Penyajian hasil analisis data dilakukan dengan penyajian deskripsi yang berupa rangkaian kata-kata.

\section{HASIL DAN PEMBAHASAN}

\section{Wujud variasi alih kode penumpang terhadap kru bus trayek Solo-Jogja}

a. Alih Kode Intern Antarbahasa

Alih kode intern antarbahasa adalah alih kode yang digunakan dari bahasa satu dengan bahasa yang lainnya dimana masih dalam satu wilayah tertentu. Biasanya kerap dilihat dalam penggunaan Bahasa Indonesia dan Bahasa Jawa.

1) Alih kode Bahasa Indonesia ke Bahasa Jawa

Alih kode ini merupakan peristiwa peralihan tindak tutur dari Bahasa Indonesia ke Bahasa Jawa. Perhatikan data percakapan berikut.

Konteks:

Penumpang 1 (perempuan yang baru pindah tempat duduk dari belakang ke depan) dan penumpang 2 (laki-laki yang sedang berbicara kepada kru bus karena sebentar lagi akan turun).

Tempat dan waktu:

Bus Eka dari arah Jogja ke Klaten. 22 Januari 2018.

Penumpang 2: Pak, turun Delanggu.

Penumpang 1: Kosong mas ini tempat duduknya?

Penumpang 2: Iyo mbak dilungguhi wae.

'Iya mbak di dudukin saja'

Penumpang 1: Njeh mas, suwun. 'Iya mas, terimakasih'

Alih kode intern tersebut bersumber dari tuturan penumpang 1 yang menggunakan

Bahasa Indonesia kemudian beralih ke Bahasa Jawa karena lawan tuturnya adalah masyarakat Jawa (penumpang 2) yang mengakibatkan penumpang 1 harus menyesuaikan bahasa yang digunakan oleh lawan tuturnya.

2) Alih kode Bahasa Jawa ke Bahasa Indonesia

Alih kode ini merupakan peralihan dari variasi Bahasa Jawa ke dalam Bahasa Indonesia. Perhatikan data percakapan berikut.

Konteks: Kru bus memberikan informasi kepada sopir bus tentang tiga bus yang tertilang polisi.

\footnotetext{
${ }^{22}$ Nyoman Kutha. Ratna, Metodologi Penelitian Kajian Budaya Dan Ilmu Sosial Humaniora Pada Umumnya. (Yogyakarta: Pustaka Pelajar).
} 
Tempat dan waktu: Di dalam bus Mira arah Delanggu ke Kartasura. 24 Januari 2018.

Kru bus : : Wingi aku melu Mira 40, bis Sugeng karo Eka ketilang polisi pak. 'Kemarin saya ikut Mira 40, bus Sugeng dan Eka ditilang polisi pak'

Sopir : : Apa iya sih Ton.

Kru bus : Iya pak.

Sopir : : Mateng langsung bis loro?

'Astaga langsung dua bus?'

Alih kode terjadi pada kru bus yang mulanya memberitahukan informasi dengan menggunakan Bahasa Jawa kemudian sopir menjawabnya dengan menggunakan Bahasa Indonesia. Akhirnya, kru bus beralih yang semula menggunakan Bahasa Jawa yang kemudian dialihkan ke dalam Bahasa Indonesia, karena lawan tuturnya menggunakan bahasa Indonesia.

b. Alih kode intern antartingkat tutur bahasa

Alih kode intern antartingkat tutur bahasa adalah alih kode yang berlangsung antara tingkat tutur bahasa satu dengan bahasa yang lainnya. Biasanya dalam tingkat tutur bahasa lebih didominasi dari Bahasa Jawa yatu Bahasa Jawa ngoko, Bahasa Jawa madya dan Bahasa Jawa krama.

1) Alih kode Bahasa Jawa madya ke Bahasa Jawa ngoko

Alih kode ini merupakan peristiwa peralihan Bahasa Jawa madya ke Bahasa Jawa ngoko. Perhatikan data percakapan berikut.

Konteks: Seorang penumpang yang ingin turun di kota Sragen yang bertanya kepada kru bus untuk segera diturunkan.

Tempat dan waktu: Bus Sugeng Rahayu dari arah Kleco ke Kartasura. 2 Februari 2018.

Penumpang : : Mengkeh mang mudunke teng ngajeng nggih pak.

'Nanti tolong diturunkan di depan ya pak'

Kru bus : Iyo, mudun bangjo ngarep iku to.

'Iya, turun lampu merah itu kan'

Penumpang : Sampun pak, kiri.

'Sudah pak, kiri'

Kru bus : Sikil kiwo sik mbak.

'Kaki kiri dulu mbak'

Penumpang : Njeh pak.

'Iya pak'

Alih kode terjadi pada tuturan penumpang karena penumpang menggunakan bentuk tuturan Bahasa Jawa madya. Mengkeh mang mudunke teng ngajeng nggih pak sebagai tindak refleks yang memberitahukan bahwa penumpang tersebut akan segera turun. Bahasa itu dialihkan menggunakan tuturan Bahasa Jawa ngoko yang dituturkan oleh kru bus sebab penumpang dianggap umurnya lebih muda daripada kru bus tersebut.

2) Alih kode Bahasa Jawa ngoko ke Bahasa Jawa madya

Alih kode ini merupakan peralihan tuturan dari Bahasa Jawa ngoko ke dalam Bahasa Jawa madya.

Konteks: Kru bus yang sedang mencari penumpang untuk segera berangkat ke Jogja dan daerah-daerah yang ada di sekitarnya. 
Tempat dan waktu: Terminal Tirtonadi di jalur 3. 6 Februari 2018.

Kru bus : Jogja jogja langsung mangkat.

'Jogja jogja langsung berangkat'

Penumpang : : Langsung mlampah niki pak.

'Langsung berangkat ini pak'

Kru bus $\quad$ : Iyo, nunggu rada akeh penumpang sik.

'Iya, tunggu sampai penumpang penuh dulu'

Penumpang : Nggih pun pak.

'Iya sudah pak'

Alih kode tersebut terjadi pada tuturan antar kru bus dan penumpang. Tuturan awal kru bus menggunakan Bahasa Jawa ngoko yang ditunjukkan pada tuturan mangkat. Berdasarkan tuturan kru bus tersebut penumpang langsung beralih menggunakan Bahasa Jawa madya pada tuturan mlampah niki sebab dianggapnya kru bus tersebut umurnya lebih tinggi dibandingkan penumpang.

3) Alih kode Bahasa Jawa ngoko ke Bahasa Jawa krama

Alih kode ini merupakan peralihan tindak tutur bahasa dari Bahasa Jawa ngoko ke Bahasa Jawa krama. Perhatikan data percakapan berikut.

Konteks: Percakapan antara kru bus kepada salah satu penumpang yang menanyakan sekolah dimana, sebab penumpang tersebut mulai naik bus dari terminal Surabaya dan anggapan kru bus tersebut penumpang tersebut tidak turun-turun.

Tempat dan waktu: Bus Eka trayek Ngawi-Sragen. 7 Februari 2018.

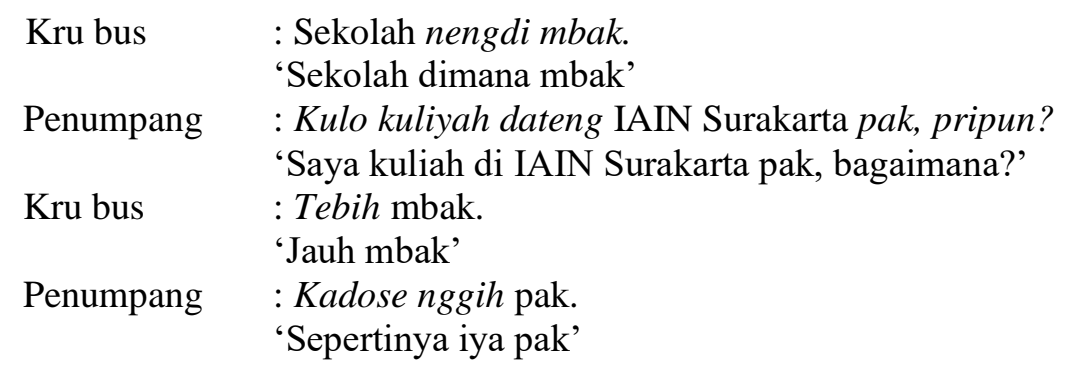

Alih kode tersebut terjadi pada tuturan penumpang karena beranggapan bahwa dalam bertindak tutur dengan kru bus harus menggunakan Bahasa Jawa krama sebab usianya lebih tinggi, karena kru bus menggunakan Bahasa Jawa ngoko pada kata nengdi, maka penumpang pun beralih ke Bahasa Jawa krama seperti pada kalimat kulo kuliyah dateng IAIN Surakarta pak, pripun?. Peralihan bahasa tersebut dilakukan untuk saling menghormati.

4) Alih kode Bahasa Jawa krama ke Bahasa Jawa ngoko

Alih kode ini merupakan peralihan tindak tutur dari Bahasa Jawa krama ke Bahasa Jawa ngoko. Perhatikan data percakapan berikut.

Konteks: Pembicaraan antara penumpang 1 dan penumpang 2 yang berada di dalam bus dengan menanyakan suatu keadaan yang sudah terjadi.

Tempat dan waktu: Bus Mira perjalanan Solo ke Delanggu. 8 Februari 2018.

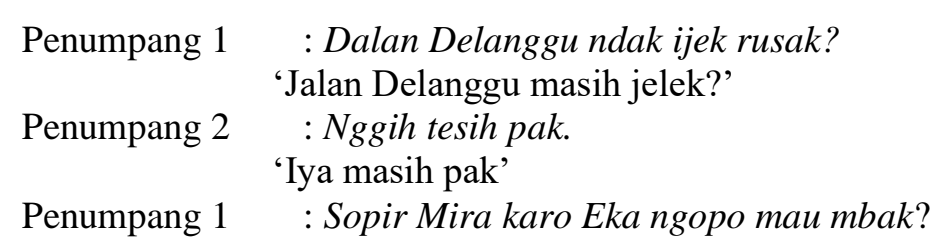




\begin{abstract}
'Sopir Mira dengan Eka tadi kenapa mbak?'
Penumpang 2 : Oh, nganu pak mau koyoe spion bis eka ketotol bis Mira.

'Oh, tadi sepertinya spion bus Eka disenggol sama bus Mira'
\end{abstract}

Alih kode tersebut terjadi pada penumpang 2 yang terlihat pada kalimat kedua $\mathrm{Nggih}$ tesih pak yang menggunakan Bahasa Jawa krama disaat melakukan tindak tutur. Meskipun penumpang 2 menggunakan Bahasa Jawa krama, tetapi penumpang satu menjawab dengan mengalihkan Bahasa Jawa ngoko 'Sopir Mira karo Eka ngopo mau mbak?', dianggapnya penumpang 1 umurnya lebih rendah daripada penumpang 2.

\title{
Fungsi Alih Kode Penumpang Terhadap Kru Bus Trayek Solo-Jogja
}

Komunikasi antara penumpang dengan kru bus dan sopir tentu memiliki maksud dan tujuan tersendiri dalam melakukan proses alih kode, baik sudah mengenal atau belum. Berikut adalah fungsi dari alih kode yang ditemukan Gumperz (dalam Abdullah, 2013:162) yang muncul pada setiap alih kode. Misalnya dalam bahasa resmi akan terlihat penutur yang cenderung untuk menggunakan ragam bahasa santai, akrab, dan tidak baku dengan gaya sedikit emosional. Pada situasi itu juga, topik pembicaraan lebih banyak mengenai pemberian informasi, keakraban, penyampaian rasa humor dan pemberian rasa aman.

a. Untuk Memberikan Informasi

Memberi informasi yaitu pemakaian alih kode bahasa yang berfungsi sebagai alat untuk memberi suatu berita atau informasi supaya dapat diketahui orang lain.

Konteks: Kru bus meminta bayaran retribusi kepada penumpang yang akan turun d Jogja.

Tempat dan waktu: Bus Eka dari arah Solo ke Kartasura. 2 Februari 2018.

$\begin{array}{ll}\text { Kru bus } & \text { : Tiket anyar, tiket anyar. } \\ \text { 'Tiket baru, tiket baru' } & \text { : Klaten- Jogja pinten pak? } \\ \text { Penumpang } & \text { 'Klaten-Jogja berapa pak?' } \\ \text { Kru bus } & : 24.000 \text { mbak. }\end{array}$

Tuturan di atas terjadi peralihan kode dari Bahasa Jawa ke Bahasa Indonesia yang dilakukan oleh kru bus. Kata pinten merupakan kata yang kemudian dialih kodekan ke dalam Bahasa Indonesia oleh penutur. Alih kode tersebut diubah sebagai bentuk pemberian informasi oleh kru bus yang dituturkan juga pada kata tiket anyar. Yang berarti memberikan informasi kepada penumpang untuk segera mempersiapkan uang registrasi pembayaran.

b. Untuk Mengakrabkan Komunikasi

Komunikasi dalam mengakrabkan adalah untuk mengungkapkan rasa persahabatan, keakraban, solidaritas pada seseorang atau lawan bicara. Fungsi alih kode ini untuk mendapatkan keuntungan dan manfaat untuk menjalin rasa keakraban untuk mengimbangi kemampuan lawan bicara dan untuk memudahkan suatu urusan dengan persoalan.

Konteks: Penumpang yang mengkode kru bus untuk turun di Solo Square.

Tempat dan waktu: Bus Mira dari Jogja ke Klaten. 7 Februari 2018.

Penumpang : Pak turun di depan Solo Square.

Kru bus : Ok siap bosku.

Penumpang : Enggeh pak, matur suwun. 


\section{Wahyu Oktavia \& Ferdian Achsani}

'Iya pak, terimakasih'

Tuturan di atas penumpang beralih kode yang semula menggunakan Bahasa Indonesia yang beralih ke dalam Bahasa Jawa. Kata bosku dalam dialog di atas berarti secara tidak langsung tuturan kru bus membuktikan bahwa kata bosku memiliki makna yang digunakan sebagai sebutan pengakraban dan persahabatan. Meskipun begitu tuturan alih kode matur suwun juga dialihkan karena penumpang menganggap usia kru bus lebih tua dari penumpang.

c. Untuk Menyampaikan Rasa Humor

Penyampaian rasa humor di dalam bus merupakan salah satu fungsi alih kode yang sering terjadi dilakukan antara kru bus, sopir dan penumpang yang dianggap sebagai bentuk kesenangan dan kegembiraan. Alih kode sering dimanfaatkan karena hal tersebut dapat menciptakan suasana yang lebih bersahabat, supaya komunikasi yang dilakukan tidak tegang, supaya tetap semangat, untuk membuat orang supaya senang dan puas, dan lain sebagainya. Alih kode ini mungkin berwujud varian, alih ragam atau alih gaya bicara.

Konteks: Kru bus yang memberikan informasi kepada penumpang saat dompetnya jatuh.

Tempat dan waktu: Bus Langsung Jaya dari Solo ke Klaten. 9 Ferbuari 2018.

Kru bus : : Mbak dompete tibo.

'Mbak dompetnya jatuh'

Penumpang : Tibo nengdi mas?

'Jatuh dimana mas?'

Kru bus

: Di hatiku.

Tuturan di atas kru bus beralih kode dari Bahasa Jawa ke Bahasa Indonesia dengan maksud mengejek salah satu penumpang pada tuturannya. Di hatiku yang menanggapi tuturan penumpang dengan kata Mbak dompete tibo dan dijawab penumpang dengan kata Tibo nengdi mas? Menimbulkan terjadinya humor di dalam bus yang menyebabkan penumpang dan kru bus tertawa.

d. Untuk Memberikan Rasa Aman Pada Penumpang

Dalam hal ini alih kode juga berfungsi untuk memberikan rasa aman pada penumpang. Pemberian rasa amana ini dilakukan oleh kru bus dan sopir guna memberikan pelayanan dan keamanan kepada setiap penumpang yang ada di dalam bus. Pemberian keamanan ini dibuktikan pada kutipan percakapan berikut.

Konteks: Pembicaraan penumpang dan kru bus mengenai tempat duduk.

Tempat dan waktu: Bus Suharno perjalanan dari Kartasura ke Klaten. 10 Februari 2018.

Kru bus $\quad$ : Lungguh mburi mbak.

'Duduk ke belakang mbak'

Penumpang : Wis gak ana panggon po pak?

'Sudah tidak ada tempat duduk lagi apa pak?'

Kru bus : : Isih siji kae ning mburi.

'Masih satu itu di belakang'

Penumpang : Iya pak, terimakasih.

Tuturan di atas mengalami alih kode pada tuturan penumpang yang semula menggunakan

Bahasa Jawa yang kemudian beralih ke dalam Bahasa Indonesia. Pada kalimat Wis gak ana panggon po pak? Yang kemudian menjawab dengan peralihan kalimat Iya pak, terimakasih. Selain itu dalam tuturan di atas juga terdapat fungsi alih kode memberikan rasa aman kepada penumpang terbukti pada kalimat Lungguh mburi mbak dimana kru bus menyuruh dan 
memberikan penawaran kepada penumpang untuk duduk di belakang daripada penumpang tidak duduk sama sekali.

\section{Faktor Penyebab Terjadinya Alih Kode Penumpang Terhadap Kru Bus Trayek Solo-Jogja}

Beberapa faktor yang menjadi penyebab terjadinya alih kode yang dipengaruhi oleh konteks dan situasi yang diuraikan sebagai berikut:

a. Pembicara dan Pribadi Pembicara

Pembicara kadang-kadang sengaja beralih kode terhdap mitra bahasa sebab pembicara memiliki maksud dan tujuan tertentu. Dapat dilihat dari kepribadian pembicara, ada sebuah tujuan dan maksud mengapa pembicara mengubah situasi dan bahasa dalam melakukan tindak tutur. Karena situasi yang terikat adalah situasi formal maka dari itu pembicara sering melakukan alih kode ke bahasa lain karena terciptanya suatu kebiasaan yang dilakukan sehari-hari.

b. Mitra Bicara

Dalam masyarakat bilingualisme mitra bicara dalam hal ini berupa tuturan individu atau kelompok. Seseorang pembicara yang pada umumnya hanya menggunakan satu bahasa dan kemudian beralih ke bahasa yang lain tentu dilatarbelakangi dengan suatu daerah tertentu. Misalnya seorang bawahan yang berbicara kepada atasannya. Atau misalnya pembicaraan penumpang dengan kru bus atau kru bus dengan sopir bus.

c. Topik

Topik merupakan salah satu faktor penyebab terjadinya alih kode. Dengan topik tertentu maka percakapan yang dilakukan ketika melakukan peralihan kode akan berjalan secara lancar. Topik dalam alih kode terbagi menjadi dua yaitu topik ilmiah dan topik non ilmiah. Topik secara ilmiah dapat disampaikan secara formal dengan menggunakan bahasa yang formal pula sedangkan topik non ilmiah disampaikan dalam situasi yang bebas dan santai dengan menggunakan ragam bahasa non formal.

\section{d. Modus Pembicaraan}

Modus pembicaraan merupakan komunikasi yang dilakukan secara langsung (tatap muka) yaitu antara mulut dengan mulut. Biasanya modus pembicaraan ini lebih banyak menggunakan ragam bahasa non formal dibandingkan dengan ragam formal. Karena penggunaan ragam bahasa non formal dianggap luas dan bebas dibandingkan dengan ragam bahasa formal sebagai sarana yang digunakan untuk berbicara. Dengan modus lisan ini akhirnya lebih sering terjadi alih kode daripada menggunakan modus tulis.

e. Tempat Tinggal dan Waktu Pembicaraan Berlangsung

Pembicaraan yang terjadi disebuah terminal bus di Indonesia biasanya dilakukan oleh berbagai kalangan, misalnya pada kalangan etnis. Oleh karena itu secara kompleks akan banyak timbul alih kode bahasa. Alih bahasa itu terjadi dari bahasa satu ke bahasa kedua yaitu dari tingkat tutur suatu bahasa ke tingkat tuturan bahasa yang lain.

f. Ragam dan Tingkat Tutur Bahasa 


\section{Wahyu Oktavia \& Ferdian Achsani}

Dalam ragam dan tingkat tutur bahasa banyak dipilih berdasarkan pada pertimbangan mitra bicara. Petimbangan ini menunjukkan suatu ragam bahasa terhadap topik tertentu atau relevansi dengan situasi tertentu. Pada hal ini, alih kode sering muncul dalam penggunaan ragam non formal dan tutur bahasa rendah dibandingkan dengan penggunaan ragam bahasa tinggi.

g. Perubahan Situasi

Hadirnya orang ketiga tentu akan membuat perubahan situasi yang tidak berlatar belakang. Dalam hal ini selaku pengguna bahasa yang sama dengan bahasa yang sedang digunakan oleh penutur dapat pula menyebabkan terjadinya alih kode.

h. Untuk Mengenal Bergengsi

Alih kode juga memiliki faktor-faktor lawan bicara, topik dan faktor sosial situasional tidak mengharapkan adanya alih kode, sehingga tampak adanya pemaksaan, tidak wajar dan tidak komunikatif. Gejala seperti ini sering kita jumpai pada gaya bahasa para anak remaja di sekitar kita.

i. Fungsi dan Tujuan

Fungsi bahasa yang digunakan dalam pembicaraan didasarkan pada tujuan berkomunikasi. Fungsi bahasa pada umumnya merupakan ungkapan yang berhubungan dengan tujuan tertentu, seperti perintah, menawarkan, mengumumkan, memarahi dan sebagainya. Pembicara alih kode yaitu menggunakan bahasa menurut fungsi yang dikehendakinya sesuai dengan konteks dan situasi komunikasi. Alih kode dapat terjadi karena situasi yang dipandang tidak sesuai atau tidak relevan. Dengan demikian alih kode menunjukkan adanya saling ketergantungan antara fungsi kontekstual dan situasional yang relevan dalam pemakaian dua bahasa atau lebih.

\section{SIMPULAN}

Dari beberapa fenomena bahasa, salah satunya alih kode penumpang terhadap kru bus trayek Solo-Jogja tersebut, dapat ditarik kesimpulan bahwa pergantian bahasa secara sadar atau penggunaan bahasa lain ketika berkomunikasi, secara tidak langsung memunculkan perilaku alih kode.

Data-data penelitian di atas dapat diketahui bahwa dalam alih kode terdapat tiga hasil penelitian (1) wujud variasi alih kode terdapat dua kategori. Pertama intern antarbahasa yaitu alih kode dari Bahasa Indonesia ke Bahasa Jawa dan alih kode dalam Bahasa Jawa ke dalam Bahasa Indonesia. Kedua alih kode intern antartingkat tutur Bahasa Jawa yaitu Bahasa Jawa krama ke Bahasa Jawa ngoko, Bahasa Jawa ngoko ke Bahasa Jawa krama, Bahasa Jawa madya ke Bahasa Jawa ngoko dan Bahasa Jawa ngoko ke Bahasa Jawa madya. (2) fungsi alih kode pada umumnya untuk memberikan informasi, mengakrabkan komunikasi, menyampaikan rasa humor, dan memberikan rasa aman kepada penumpang. (3) faktor-faktor yang mempengaruhi alih kode yaitu pembicara dan pribadi pembicara, mitra bicara, topik, modus pembicaraan, tempat tinggal dan waktu pembicaraan berlangsung, untuk mengenal bergengsi, fungsi dan bahasa serta ragam dan tingkat tutur bahasa. 
Berdasarkan keseluruhan analisis data yang sudah diteliti, juga ditemukan pemendekan kata yang terdapat pada setiap tuturan yang dilakukan oleh penumpang, sopir dan kru bus yang ada di dalam bus. Dimana tuturan yang disingkatnya adalah seperti pada kata terminal menjadi minal, jogja menjadi ja ja, dan sebagainya.dalam hal ini tentu berkaitan dengan fungsi alih kode yang terjadi pada tuturan penumpang, sopir dan kru bus trayek Solo-Jogja.

\section{DAFTAR PUSTAKA}

Abdul Chaer. 2007. Linguistik Umum. Jakarta: Rieneka Cipta.

Abdullah, Alek dan Achmad. 2013. Linguistik Umum. Jakarta: Erlangga.

Chaer, Abdul dan Agustina Leonie. 2004. Sosiolinguistik. Jakarta: PT Rineka Cipta

Giyoto. 2013. Pengantar Sosiolinguistik. Surakarta: Fataba Press.

Kridalaksana, Kristen. 1986. The Linguistics Encyclopedia. London:Routledge.

Mustikawati, Diyah Atiek. 2015. Alih Kode Dan Campur Kode Antara Penjual Dan Pembeli (Analisis Pembelajaran Berbahasa Melalui Studi Sosiolinguistik). Dimensi Pendidikan dan Pengajaran, 3 (2): 1-10.

Nababan, P. W. J. 1986. Sosiolinguistik: Suatu Pengantar. Jakarta: PT Gramedia.

Nugroho, A. 2011. Alih Kode dan Campur Kode pada Komunikasi Guru-Siswa di SMA Negeri 1 Wonosari Klaten (Skripsi). Yogyakarta: Program Sarjana Universitas Negeri Yogyakarta.

Patmawati, Priliana Budi. 2013. Campur Kode dan Alih Kode Pada Acara Show Imah di Trans TV (Skripsi). Jember: Program Sarjana Universitas Jember.

Putri, Dewi Lagawati. 2013. Alih Kode Dalam Acara Talk Show "Show Imah" di Trans TV (Skripsi). Yogyakarta: Program Sarjana Universitas Negeri Yogyakarta.

Ratna, Nyoman Kutha. 2010. Metodologi Penelitian Kajian Budaya dan Ilmu Sosial Humaniora Pada Umumnya. Yogyakarta: Pustaka Pelajar.

Sumarsono. 2008. Sosiolinguistik. Yogyakarta: Sabda.

Suwito. 1985. Sosiolinguistik Pengantar Awal. Surakarta: Henary Offset Solo.

Thesa, Khodiyo. 2017. Penggunaan Alih Kode Dalam Percakapan Pada Jaringan WhatsApp Oleh Mahasiswa KNB Yang Berkuliah Di Universitas Sebelas Maret. Prasasti, 2(1): 89101.

Wulansari, Nanik. 2013. Wujud dan Fungsi Alih Kode Penumpang dan Awak Bus Trayek Jepara-Semarang (Skripsi). Semarang: Program Sarjana Universitas Diponegoro Semarang. 